\title{
Pregnancy Outcome in Women Having Oligohydramnios in Gandaki Medical College Teaching Hospital, Pokhara, Nepal
}

\author{
Tripathi $\mathrm{M}^{1}$, Gurung $\mathrm{T}^{2}$, Ghale $\mathrm{TM}^{3}$, Gurung $\mathrm{B}^{4}$, Pandit $\mathrm{C}^{2}$, Shrestha $\mathbf{R}^{1}$, Adhikari $\mathrm{A}^{2}$, Sherchan $\mathrm{K}^{2}$ \\ ${ }^{1}$ Associate Professor, ${ }^{2}$ Lecturer, ${ }^{4}$ Professor, Department of Obstetrics and Gynaecology, \\ PProfessor, Department of Anesthesiology, \\ Gandaki Medical College \& Teaching Hospital, Pokhara, Nepal
}

\author{
Keywords \\ Amniotic fluid index, Pregnancy \\ outcome, Term pregnancy.

\section{Corresponding author \\ *Dr. Malati Tripathi \\ Professor \& Head \\ Department of Obstetrics \& Gynecology \\ Gandaki Medical College \& Teaching \\ Hospital, Pokhara, Nepal \\ E-mail: drmalatitripathi@hotmail.com}

\begin{abstract}
Background: Amniotic fluid index is one of the most commonly used methods of amniotic fluid volume assessment and is a predictor of adverse maternal and perinatal outcome.
\end{abstract}

Objectives: To compare the maternal and perinatal outcome in women with singleton term pregnancies having amniotic fluid index (AFI) $\leq 5 \mathrm{~cm}$ to those having AFI $\geq 5$ to $20 \mathrm{~cm}$.

Methods: This is a prospective, case-control study which was conducted at Gandaki Medical College Teaching Hospital over a period of one year from July 2017 to July 2018. It included 60 pregnant women at term pregnancy with amniotic fluid index $\leq 5 \mathrm{~cm}$. The control group included 60 pregnant women at term pregnancy with amniotic fluid index $\geq 5 \mathrm{~cm}$. The two groups were compared. Statistical analysis was done using the Chi-square test to calculate the P-value.

Results: There was a significantly higher incidence of overall cesarean rates due to fetal distress, low birth weight babies and adverse neonatal outcome like 5 minute Apgar score $\leq 7$, neonatal intensive care unit (NICU) admission rates, and meconium aspiration syndrome in the group with oligohydramnios as compared to the group with normal liquor volume.

Conclusion: Oligohydramnios adversely affects the perinatal outcome. However a favorable outcome can be expected by good antenatal and intrapartum surveillance and neonatal care.

\section{INTRODUCTION}

Amniotic fluid surrounds the fetus everywhere except at its attachment with the body stalk in the mother's womb. Amniotic fluid index (AFI) as described by Phelan and coworkers, in 1987, remains one of the most commonly used methods of amniotic fluid volume assessment. The AFI is the sum of the single deepest pocket from each quadrant. The normal range for AFI that is most commonly used is 5 to $24 \mathrm{~cm}$, with values above and below this indicating hydramnios and oligohydramnios respectively ${ }^{1}$.
Oligohydramnios is defined as amniotic fluid volume more than two standard deviation below the mean for specific gestational age or volume reduced below the fifth percentile for particular gestational age ${ }^{2}$. Late onset oligohydramnios has increased incidence of meconium stained liquor, abnormal fetal heart rate (FHR) tracing, low Apgar score, low birth weight, admission to NICU, birth asphyxia and cesarean section for fetal distress ${ }^{3}$. Clinical estimation of amniotic fluid volume is an important part of fetal assessment as variation in its amount has been related to a variety of pregnancy complications $s^{4,5}$. 
Oligohydramnios in pregnancy is related to increased maternal and fetal morbidity and mortality. Hence, this study was carried out to find the association of oligohydramnios with mode of delivery and perinatal outcome at term pregnancy in Western part of Nepal.

\section{MATERIALS AND METHODS}

This prospective study was conducted in Gandaki Medical College Teaching Hospital (GMCTH), Pokhara, Nepal over a period of one year from July 2017 to July 2018. A pregnancy outcome in 60 women with ultrasound diagnosis of oligohydramnios after 37 completed weeks of gestation was compared with 60 women with no oligohydramnios mother with same age and parity. All the pregnant women were admitted in maternity ward and those who fulfilled the study criteria were taken for the study purpose.

This study includes an analysis of mode of delivery, meconium passage, birth weight, Apgar score, neonatal intensive care unit admissions and neonatal deaths. Cases with AFI $\leq 5$, Single live intrauterine gestation with cephalic presentation, 37 completed weeks of gestation and intact membrane were included in the study. Cases $A F I \geq 5$, gestational age $<37$ completed weeks, post-term, Associated fetal malformations, ruptured membranes, malpresentation and multiple gestation and high-risk pregnancy having placental insufficiency, diabetes, chronic renal disease, connective tissue disorders abruption, prostaglandin syntheses inhibitors therapy, angiotensinogen converting enzyme inhibitors therapy, uterine scar due to previous lower segment cesarean section (LSCS), myomectomy, hysterotomy were excluded from the study.

Ethical approval was granted by the institutional review committee of the GMCTH to conduct the study. Informed verbal consent was taken from the patient. A detailed history was taken and examination was done in patients with ultrasonography (USG). The ultrasound transducer was held perpendicular to the floor and parallel to the long axis of the pregnant women. The uterus was divided into four equal quadrants, the right and left upper and lower quadrants, respectively; sum of four quadrants is amniotic fluid Index. The oligohydramnios group (AFI $<5$ $\mathrm{cm}$ ) was compared with no-oligohydramnios group (AFI $5-20 \mathrm{~cm}$ ). Variables like age and parity, mode of delivery, intrapartum complication, and fetal outcomes were noted. At birth, Apgar score, birth weight, and sex of the baby were recorded. Neonates who were admitted in the ward and Neonatal Intensive Care Unit (NICU) were followed till discharge.

Data was collected and compiled in MS-Excel 2010 and analysed using Chi-square test to compare the categorical variables. The $p$-value $<0.05$ was considered significant. All the analysis was carried out on SPSS software in 21.0 version.

\section{RESULTS}

During one year duration, 60 patients who completed 37 weeks of gestation with $\mathrm{AFI}<5 \mathrm{~cm}$ and met inclusion criteria were included in the oligohydramnios group. These patients were compared with 60 patients in nooligohydramnios group (AFI 5 to $20 \mathrm{~cm}$ ) after matching age group and parity. Both groups were followed to document the mode of delivery and neonatal outcome (Table 1).

Table 1: Maternal age and parity

\begin{tabular}{lccccc}
\hline \multicolumn{1}{c}{$\begin{array}{c}\text { Maternal } \\
\text { age }\end{array}$} & \multicolumn{2}{c}{ Study group } & \multicolumn{2}{c}{ Control group } & p- val- \\
\cline { 2 - 5 } & No. & $\mathbf{\%}$ & No. & $\%$ & \\
Teenage & 12 & 20 & 12 & 20 & 1 \\
20 to 30 years & 48 & 80 & 48 & 80 & \\
Parity & & & & & \\
Primigravida & 9 & 15 & 9 & 15 & 1 \\
Multigravida & 51 & 85 & 51 & 85 & \\
\hline
\end{tabular}

From Table 1, it was observed that $20 \%$ of women with oligohydramnios were in the teenage group and $80 \%$ were in age group between $20-30$ years. By parity $15 \%$ were primigravida followed by $85 \%$ multigravidas.

Table 2: Colour of liquor

\begin{tabular}{|c|c|c|c|c|c|}
\hline \multirow[t]{2}{*}{ Color of liquor } & \multicolumn{2}{|c|}{ Study group } & \multicolumn{2}{|c|}{ Control group } & \multirow[t]{2}{*}{ p-value } \\
\hline & No. & $\%$ & No. & $\%$ & \\
\hline Liquor clear & 30 & 50 & 52 & 86.7 & $<0.001$ \\
\hline $\begin{array}{l}\text { Thin meconium } \\
\text { Stain liquor }\end{array}$ & 22 & 36.7 & 6 & 10 & 0.001 \\
\hline $\begin{array}{l}\text { Moderate meconium } \\
\text { stain liquor }\end{array}$ & 5 & 8.3 & 1 & 1.7 & 0.209 \\
\hline $\begin{array}{l}\text { Thick meconium } \\
\text { stain liquor }\end{array}$ & 3 & 5 & 1 & 1.7 & 0.611 \\
\hline
\end{tabular}

In presence of oligohydramnios, the occurrence of moderate and thick meconium stained were more, but statistically the difference between study and control group was non-significant (Table 2). 
Table 3: Mode of delivery

\begin{tabular}{|c|c|c|c|c|c|}
\hline \multirow{2}{*}{$\begin{array}{l}\text { Mode of } \\
\text { delivery }\end{array}$} & \multicolumn{2}{|c|}{ Study group } & \multicolumn{2}{|c|}{ Control group } & \multirow[b]{2}{*}{$P$ value } \\
\hline & No. & $\%$ & No. & $\%$ & \\
\hline Normal delivery & 11 & 18.3 & 54 & 90 & $<0.001$ \\
\hline Vacuum delivery & 6 & 10 & 2 & 3.3 & 0.272 \\
\hline Cesarean section & 43 & 71.7 & 4 & 6.7 & $<0.001$ \\
\hline
\end{tabular}

As regards to mode of delivery, it was observed that $71.7 \%$ had cesarean and $18.3 \%$ had normal delivery in oligohydramnios group. There was statistically significant difference $(\mathrm{p}<0.001)$ between study and control group (Table 3).

Table 4: Neonatal outcome

\begin{tabular}{lcccccc}
\hline & & \multicolumn{3}{c}{ Study group } & \multicolumn{3}{c}{ Control group } & \\
\cline { 3 - 6 } & & No. & $\%$ & No. & $\%$ & p-value \\
Apgar & $>7$ & 49 & 81.7 & 58 & 96.7 & \\
$\begin{array}{l}\text { score in } 5 \\
\text { minute }\end{array}$ & $\leq 7$ & 11 & 18.3 & 2 & 3.3 & 0.008 \\
Neonate & $>2.5$ gram & 50 & 83.3 & 57 & 95 & \\
weight & $\leq 2.5$ gram & 10 & 16.7 & 3 & 5 & 0.040 \\
& NICU & 12 & 20 & 3 & 5 & 0.013 \\
Neonate & Pediatric ward & 3 & 5 & 0 & - & 0.244 \\
admis- & Baby with mother & 45 & 75 & 57 & 95 & 0.002 \\
sion & Perinatal death & 0 & & 0 & & \\
\hline
\end{tabular}

Oligohydramnios was significantly associated with poor Apgar score, decreased neonate weight and increased neonate admission (Table 4).

\section{DISCUSSION}

The objective of the present study was to compare the maternal and perinatal outcome in women with singleton term pregnancies having amniotic fluid index (AFI) $\leq 5 \mathrm{~cm}$ to those having AFI $\geq 5$ to $20 \mathrm{~cm}$. Assessment of amniotic fluid volume during the antenatal period is an important marker of fetal well being and considered a helpful tool in determining who is at risk for adverse neonatal outcome $\mathrm{e}^{6}$.

The present study assessed oligohydramnios with mode of delivery, color of liquor and neonatal outcome. In our study, there was no significant difference in age with oligohydramnios ( $\mathrm{p}$-value $=1$ ) which is similar to previous study ${ }^{7}$. Conversely, the incidence of oligohydramnios was $85 \%$ in multigravida, which was in contrast to Jandial et $a l$ and Petrozella et al who noticed that the incidence of oligohydramnios was $60.0 \%$ in primipara ${ }^{8,9,10}$. However, difference was statistically non-significant.

Regarding the color of liquor, our result is similar to that of Alchalabi et al where meconium staining of the amniotic fluid was significantly higher in the group with AFI $<5$ $\mathrm{cm}^{11}$.

In this study, the rate of normal delivery was $18.30 \%$ in oligohydromnios group and $90 \%$ in no-oligohydramnios group. Various studies show different rates of cesarean deliveries in oligohydromnios patients while comparing with no-oligohydramnios group. In our study, the rate of cesarean section was higher in oligohydramnios $(71.7 \%$ vs. $6.7 \%$ ) and difference was statistically significant. These results correlate with the results of the study carried out by Nazlima and Fatima who found that $71 \%$ of women underwent cesarean in oligohydramnios group ${ }^{6}$.

Concerning the neonatal outcome, our study showed statistically significant low Apgar score in oligohydramnios $(18.3 \%$ vs. $3.3 \%)$ compared to no-oligohydramnios group. Similar results were observed by several studies ${ }^{12,13,14,15,16}$. On the contrary, Rainford et al noticed no significant differences in APGAR scores between the two groups ${ }^{17}$. The present study showed no significant differences in birth weight of babies ( $\mathrm{P}=0.014(>2.5 \mathrm{gm})$ and $0.013(<2.5$ $\mathrm{gm})$. Results of this strongly correlate with studies done by Alchalabi et al and Gupta et a ${ }^{11,18}$.

In the present study, there was no neonatal death in both study and control group. NICU admission was found to be significantly higher in oligohydramnios $(P=0.013)$ group compared to no-oligohydramnios group. Our result was similar to previous studies ${ }^{13,19,20}$, but was in contrast other studies $^{11,17,21}$.

\section{CONCLUSION}

There are several adverse effects of oligohydramnios atterm pregnancy on the perinatal outcome. An AFI $\leq 5$ detected at term is an indicator for poor pregnancy outcome. However, Antepartum fetal assessment tests, intensive intrapartum monitoring coupled with timely intervention, a competent neonatologist and neonatal intensive care unit facility can reduce maternal and fetal morbidity and mortality. 


\section{REFERENCES}

1. William's Obstetrics, 24th edition; Cunningham, Leveno, Bloom, Dashe. McGraw Hill; 233.

2. Mishra R Ian Donald's practical obstetric problems. (6 $6^{\text {th }}$ edn. 2007), BI Publication Pvt Ltd, New Delhi, India, pp. 365.

3. McCurdy CM Jr, Seeds JW. Oligohydramnios: Problems and treatment. Semin Perinatol. 1993; 17: 183-196.

4. Chamberlain PF, Manning FA, Morrison I, et al. The relationship of marginal and decreased amniotic fluid volumes to perinatal outcome. Am J Obstet Gynecol. 1984; 150(3): 245-49.

5. Nageotte MP, Towers CV, Asrat T, Freeman RK. Perinatal outcome with the modified biophysical profile. Am J Obstet Gynecol. 1994; 170(6): 1672-6.

6. Nazlima N, Fatima B. Oligohydramnios at third trimester and perinatal outcome. Bangladesh J Med Sci. 2012; 11: 33-6.

7. Chauhan SP, Sanderson M, Hendrix NW, Magann EF, Devoe LD. Perinatal outcome and amniotic fluid index in the antepartum and intrapartum periods: A meta-analysis. Am J Obstet Gynecol. 1999; 181: 1473-8.

8. Jagatai K, Singh N, Patel S. Maternal and fetal outcome in oligohydramnios: A study of 100 cases. Int J Med Sci Public Health. 2013; 2: 724-7.

9. Jandial C, Gupta S, Sharma S, Gupta M. Perinatal outcome after antepartum diagnosis of oligohydraminos at or beyond 34 weeks gestation. J KSci. 2007; 9: 213-4.

10. Petrozella LN, Dashe JS, McIntire DD, Leveno KJ. Clinical significance of borderline amniotic fluid index and oligohydramnios in preterm pregnancy. Obstet Gynecol. 2011; 117 (2 Pt 1): 338-42.

11. Alchalabi HA, Obeidat BR, Jallad MF, Khader YS. Induction of labor and perinatal outcome: The impact of amniotic fluid index. Eur J Obstet Gynecol
Reprod Biol. 2006 Dec; 129(2): 124-7.

12. Chandra PC, Schiavello HJ, Lewandowski MA. Effect of oral and intravenous hydration on oligohydramnios. J Reprod Med. 2000; 45: 337-40.

13. Chate P, Khatri M, Hariharan C. Pregnancy outcome after diagnosis of oligohydramnios at term. IJRCOG. 2013; 2(1): 23-6.

14. Ashwal E, Hiersch L, Melamed N, Aviram A, Wiznetzer A, Yegev Y. Association between isolated oligohydramnios at term and pregnancy outcome. Arch Gynecol Obstet. 2014 Nov; 290 (5): 875-81. doi 10.1007/s00404-014-3292-7.

15. Bachhav AA, Waikar M. Low amniotic fluid index at term as a predictor of adverse perinatal outcome. $J$ Obstet Gynaecol India. 2014 Apr; 64 (2): 120-23.

16. Dizon-Towson D, Kennedy K, Dildy G, et al. Amniotic fluid index and perinatal morbidity. Am J Perinatal. 1996; 13: 231.

17. Rainford M, Adair R, Scialli AR, et al. Amniotic fluid index in the uncomplicated term pregnancy. Prediction of outcome. J Reprod Med. 2001; 46(6): 589-592. [PubMed].

18. Gupta SK, Prasad PN, Shakya YL, Sthapit R. A study on fetal weight in oligohydraminos. JSSN. 2013; 16: 73-8.

19. Johnson JM, Chauhan SP, Ennen CS, Niederhauser A, Magann EF. A comparison of 3 criteria of oligohydramnios in identifying peripartum complications: A secondary analysis. Am J Obstet Gynecol. 2007; 197: 207.e1-7.

20. Sriya R, Singhal S. Perinatal outcome in patients with amniotic fluid index $<5 \mathrm{~cm}$. J Obstet Gynaecol India. 2001; 51: 98-100.

21. Chauhan SP, Washburne JF, Magann EF, Perry KG Jr, Martin JN Jr, Morrison JC. A randomized study to assess the efficacy of the amniotic fluid index as a fetal admission test. Obstet Gynecol. 1995 Jul; 86(1): 9-13. 